\title{
DETERMINANTS OF COMMERCIAL BANKS' LIQUIDITY IN HUNGARY
}

\author{
Pavla Vodová ${ }^{1}$ \\ ${ }^{1}$ Slezská univerzita, Obchodně podnikatelská fakulta, Univerzitní nám. 1934/3,73340 Karviná \\ Email:vodova@opf.slu.cz
}

\begin{abstract}
As liquidity problems of some banks during global financial crisis showed, liquidity is very important for functioning of financial markets and the banking sector. This paper therefore aims to identify determinants of liquidity of Hungarian commercial banks. The data cover the period from 2001 to 2010. Results of panel data regression analysis show that bank liquidity is positively related to capital adequacy of banks, interest rate on loans and bank profitability and negatively related to the size of the bank, interest margin, monetary policy interest rate and interest rate on interbank transaction. The relation between the growth rate of gross domestic product and bank liquidity is ambiguous.
\end{abstract}

Keywords: Hungarian commercial banks, liquidity ratio, liquidity risk, panel data regression analysis.

JEL classification: C23, G01, G21

Doručeno redakci: 13.2.2013; Recenzováno: 22.2.2013; 26.2.2013; Schváleno k publikování: 13.3.2013

\section{Introduction}

Liquidity is the ability of bank to fund increases in assets and meet obligations as they come due, without incurring unacceptable losses (BIS, 2008). Liquidity risk arises from the fundamental role of banks in the maturity transformation of short-term deposits into long-term loans. It includes two types of risk: funding liquidity risk and market liquidity risk. Funding liquidity risk is the risk that the bank will not be able to meet efficiently both expected and unexpected current and future cash flow and collateral needs without affecting either daily operations or the financial condition of the firm. Market liquidity risk is the risk that a bank cannot easily offset or eliminate a position at the market price because of inadequate market depth or market disruption.

According to Aspachs et al. (2005), there are three mechanisms that banks can use to insure against liquidity crises: (i) Banks hold buffer of liquid assets on the asset side of the balance sheet. A large enough buffer of assets such as cash, balances with central banks and other banks, debt securities issued by governments and similar securities or reverse repo trades reduce the probability that liquidity demands threaten the viability of the bank. (ii) Second strategy is connected with the liability side of the balance sheet. Banks can rely on the interbank market where they borrow from other banks in case of liquidity demand. However, this strategy is strongly linked with market liquidity risk. (iii) The last strategy concerns the liability side of the balance sheet, as well. The central bank typically acts as a Lender of Last Resort to provide emergency liquidity assistance to particular illiquid institutions and to provide aggregate liquidity in case of a system-wide shortage.

During global financial crisis, many banks struggled to maintain adequate liquidity. In order to sustain the financial system, unprecedented levels of liquidity support were required from central banks (Černohorský et al., 2010). Even with such extensive support, a number of banks failed, were forced into mergers or required resolution (BIS, 2009; Teplý, 2011). The crisis showed the importance of adequate liquidity risk measurement and management. 
It is evident that liquidity and liquidity risk is very up-to-date and important topic. The aim of this paper is therefore to identify determinants of liquidity of Hungarian commercial banks.

\section{Methodology and data}

As in case of our previous studies about determinants of liquidity of Czech and Slovak commercial banks (Vodová, 2011; Vodová, 2012), in order to identify determinants of liquidity of Hungarian commercial banks we use the panel data regression analysis. For each liquidity ratio, we estimate equation (1):

$$
L_{i t}=\alpha+\beta^{\prime} \cdot X_{i t}+\delta_{i}+\varepsilon_{i t},
$$

where $L_{i t}$ is one of three liquidity ratios for bank $i$ in time $t, X_{i t}$ is a vector of explanatory variables for bank $i$ in time $t, \alpha$ is constant, $\beta^{\prime}$ are coefficient which represents the slope of variables, $\delta_{i}$ denotes fixed effects in bank $i$ and $\varepsilon_{i}$ is the error term.

Liquidity ratios are various balance sheet ratios which should identify main liquidity trends. These ratios reflect the fact that bank should be sure that appropriate, low-cost funding is available in a short time. This might involve holding a portfolio of assets than can be easily sold (cash reserves, minimum required reserves or government securities), holding significant volumes of stable liabilities (especially deposits from retail depositors) or maintaining credit lines with other financial institutions.

Various authors like Andries (2009), Aspachs et al. (2005), Bunda and Desquilbet (2008), Ghosh (2010), Jiménez et al. (8), Maechler (2007), Moore (2010), Praet and Herzberg (2008), Rychtárik (2009) or Tamirisa and Igan (2008) provide various liquidity ratios. For the purpose of this research we will use three different liquidity ratios (2) - (4).

The liquidity ratio $L 1$ should give us information about the general liquidity shock absorption capacity of a bank (2):

$$
L 1=\frac{\text { liquid assets }}{\text { total assets }}
$$

where cash, balances with central banks and other banks, debt securities issued by governments and similar securities or reverse repo trades belong to liquid assets. As a general rule, the higher the share of liquid assets in total assets, the higher the capacity to absorb liquidity shock, given that market liquidity is the same for all banks in the sample. Nevertheless, high value of this ratio may be also interpreted as inefficiency. Since liquid assets yield lower income liquidity bears high opportunity costs for the bank. Therefore it is necessary to optimize the relation between liquidity and profitability.

The liquidity ratio L2 uses concept of liquid assets as well. However, this ratio is more focused on the bank's sensitivity to selected types of funding: we included deposits of households, enterprises, and banks and other financial institutions and funds from debt securities issued by the bank (3):

$$
L 2=\frac{\text { liquid assets }}{\text { deposits }+ \text { short term borrowing }}
$$


which enables us to capture the bank's vulnerability related to these funding sources. The higher is the value of the ratio, the higher is the capacity to absorb liquidity shock.

The liquidity ratio $L 3$ is very similar to the liquidity ratio $L 2$. However, it includes only deposits to households and enterprises (4):

$$
L 3=\frac{\text { liquid assets }}{\text { deposits }}
$$

so in contrast to the ratio $L 2$, the ratio $L 3$ measures the liquidity of a bank assuming that the bank cannot borrow from other banks in case of liquidity need. This is relatively strict measure of liquidity but it enables us to capture at least the part of the market liquidity risk. The bank is able to meet its obligations in terms of funding (the volume of liquid assets is high enough to cover volatile funding) if the value of this ratio is $100 \%$ or more. Lower value indicates a bank's increased sensitivity related to deposit withdrawals.

The disadvantage of these liquidity ratios lies the fact that they do not always capture all, or any of liquidity risk. However, there are still in common. It is possible to calculate them only on the basis of publicly available data from banks' balance sheets and it is easy to interpret their values.

It is evident that the most important task is to choose the appropriate explanatory variables. Although liquidity problems of some banks during global financial crisis re-emphasized the fact that liquidity is very important for functioning of financial markets and the banking sector, an important gap still exists in the empirical literature about liquidity and its measuring. Only few studies aim to identify determinants of liquidity.

Bank-specific and macroeconomic determinants of liquidity of English banks studied Valla et al. (2006). They assumed that the liquidity ratio as a measure of the liquidity should be dependent on following factors (estimated influence on bank liquidity in parenthesis): probability of obtaining the support from lender of last resort, which should lower the incentive for holding liquid assets (-); interest margin as a measure of opportunity costs of holding liquid assets (-); bank profitability, which is according to finance theory negatively correlated with liquidity (-); loan growth, where higher loan growth signals increase in illiquid assets (-); size of the bank (?); gross domestic product growth as an indicator of business cycle (-); short term interest rate, which should capture the monetary policy effect (-).

Determinants of liquidity risk of banks from emerging economies with panel data regression analysis are analysed by Bunda and Desquilbet (2008). The liquidity ratio as a measure of bank's liquidity assumed to be dependent on individual behavior of banks, their market and macroeconomic environment and the exchange rate regime, i.e. on following factors: total assets as a measure of the size of the bank (-); the ratio of equity to assets as a measure of capital adequacy $(+)$; the presence of prudential regulation, which means the obligation for banks to be liquid enough $(+)$; the lending interest rate as a measure of lending profitability $(-)$; the share of public expenditures on gross domestic product as a measure of supply of relatively liquid assets $(+)$; the rate of inflation, which increases the vulnerability of banks to nominal values of loans provided to customers $(+)$; the realization of a financial crisis, which could be caused by poor bank liquidity (-); the exchange rate regime, where banks in countries with extreme regimes (the independently floating exchange rate regime and hard pegs) were more liquid than in countries with intermediate regimes. 
The empirical analysis of the hypothesis that interest rates affect banks' risk taking and the decision to hold liquidity across European countries provides Lucchetta (2007). The liquidity measured by different liquidity ratios should be influenced by: behavior of the bank on the interbank market - the more liquid the bank is the more it lends in the interbank market $(+)$; interbank rate as a measure of incentives of banks to hold liquidity (+); monetary policy interest rate as a measure of banks ability to provide loans to customers (-); share of loans on total assets and share of loan loss provisions on net interest revenues, both as a measure of risk-taking behavior of the bank, where liquid banks should reduce the risk-taking behavior (); bank size measured by logarithm of total bank assets (+).

The effects of the financial crisis on the liquidity of commercial banks in Latin America and Caribbean countries investigated Moore (2010). Liquidity should depend on: cash requirements of customers, captured by fluctuations in the cash-to-deposit ratio (-); current macroeconomic situation, where a cyclical downturn should lower banks' expected transactions demand for money and therefore lead to decreased liquidity (+); money market interest rate as a measure of opportunity costs of holding liquidity (-).

Liquidity created by Germany's state-owned savings banks and its determinants has been analyzed by Rauch et al. (2010). According to this study, following factors can determine bank liquidity: monetary policy interest rate, where tightening monetary policy reduces bank liquidity (-); level of unemployment, which is connected with demand for loans (-); savings quota (+); level of liquidity in previous period (+); size of the bank measured by total number of bank customers (-); bank profitability (-).

Entirely unique is the approach of Fielding and Shortland (2005). They considered these determinants of liquidity: level of economic output $(+)$; discount rate $(+)$; reserve requirements (?); cash-to-deposit ratio (-); rate of depreciation of the black market exchange rate $(+)$; impact of economic reform (-); violent political incidence $(+)$.

Studies cited above suggest that commercial banks' liquidity is determined both by bank specific factors (such as size of the bank, profitability, capital adequacy and factors describing risk position of the bank) as well as macroeconomic factors (such as different types of interest rates, interest margin or indicators of economic environment). It can be useful to take into account some other influences, such as the realization of financial crisis, changes in regulation or political incidents.

The selection of variables was based on above cited relevant studies. We considered whether the use of the particular variable makes economical sense in Hungarian conditions. For this reason, we excluded from the analysis variables such as political incidents of impact of economic reforms. We also considered which other factors could influence the liquidity of Hungarian banks. The limiting factor then was the availability of some data. Table 1 shows a list of variables which we have used in regression analysis. 
Table 1: Variables Definition

\begin{tabular}{|l|l|c|}
\hline Variable & Source & Estim.eff. \\
\hline CAP: share of equity on total assets of the bank & annual reports & + \\
\hline NPL: share of non-performing loans on total volume of loans & annual reports & - \\
\hline ROE: share of net profit on banks' equity & annual reports & - \\
\hline TOA: logarithm of total assets of the bank & annual reports & $+/-$ \\
\hline $\begin{array}{l}\text { FIC: dummy variable for financial crisis (1 in 2009 and 2010, 0 in rest } \\
\text { of the period) }\end{array}$ & own & - \\
\hline GDP: growth rate of gross domestic product & IMF & + \\
\hline INF: inflation rate & IMF & + \\
\hline IRB: interest rate on interbank transactions & IMF & - \\
\hline IRL: interest rate on loans & IMF & - \\
\hline $\begin{array}{l}\text { IRM: difference between interest rate on loans and interest rate on } \\
\text { deposits }\end{array}$ & IMF & - \\
\hline MIR: monetary policy interest rate (discount rate) & IMF & - \\
\hline UNE: unemployment rate & IMF & - \\
\hline
\end{tabular}

Source: author's processing

We consider four bank specific factors and eight macroeconomic factors. As it can be seen from Table 1, we expect that three factors could have positive impact on bank liquidity, the rest of factors are expected to have negative impact on bank liquidity. Macroeconomic data were provided by International Financial Statistics of International Monetary Fund (IMF). Bank specific data were obtained from annual reports of Hungarian banks. We used unconsolidated balance sheet and profit and loss data over the period from 2001 to 2010. The panel is unbalanced as some of the banks do not report over the whole period of time. We have excluded specialized banks such as Hungarian development bank and all building societies.

Table 2: Data Availability

\begin{tabular}{|l|l|l|l|l|l|l|l|l|l|l|}
\hline Indicator & 01 & 02 & 03 & 04 & 05 & 06 & 07 & 08 & 09 & 10 \\
\hline Total number of banks & 41 & 39 & 38 & 35 & 34 & 37 & 38 & 36 & 35 & 35 \\
\hline Number of observed banks & 18 & 23 & 24 & 26 & 29 & 28 & 27 & 26 & 23 & 21 \\
\hline $\begin{array}{l}\text { Share of observed banks on total } \\
\text { assets (in \%) }\end{array}$ & 74 & 87 & 86 & 87 & 88 & 89 & 89 & 88 & 88 & 87 \\
\hline
\end{tabular}

Source: author's processing

Table 2 shows more details about the sample. As it includes substantial part of the Hungarian banking sector, we used fixed effects regression.

\section{Results and discussion}

We use an econometric package EViews 7. After tests of stationarity, we proceed with regression estimation. We estimate equation (1) separately for each of four defined liquidity ratios. We gradually change the content of the vector of explanatory variables $X_{i t}$. The aim is to find a model which has a high adjusted coefficient of determination and simultaneously the variables used are statistically significant. As it can be seen from following tables, results of the analysis suggest that different liquidity ratios are determined by different factors.

If we measure liquidity with ratio $L 1$, we find determinants of liquidity in Table 3 . The explanatory power of this model is very high and signs of coefficients correspond with our expectations. The impact of the size of the bank on its liquidity is negative: liquidity is decreasing with the size of the bank. It seems that big banks insure against liquidity crises mainly by passive strategies: they rely on the interbank market or on a liquidity assistance of the Lender of Last Resort. This finding fully correspond to the well known "too big to fail" 
hypothesis. If big banks are seeing themselves as "too big to fail", their motivation to hold liquid assets is limited.

Table 3: Determinants of Liquidity Measured by L1

\begin{tabular}{|l|c|c|}
\hline Variable & Coefficient & Standard deviation \\
\hline Constant & $87.13662^{*}$ & 19.30075 \\
\hline TOA & $-5.095472^{*}$ & 1.546050 \\
\hline CAP & $0.238202 * *$ & 0.094421 \\
\hline GDP & $0.344432 * * *$ & 0.211787 \\
\hline Adjusted R & \multicolumn{2}{|c|}{0.834316} \\
\hline Total observations & \multicolumn{2}{|c|}{258} \\
\hline
\end{tabular}

Source: author's estimation

Note: The starred coefficient estimates are significant at the $1 \%(*), 5 \%(* *)$ or $10 \%(* * *)$ level.

The positive influence of the share of capital on total assets is consistent with the assumption that bank with sufficient capital adequacy should be liquid, too. Although most studies assumed the negative link between business cycle and bank liquidity, the results show that the approach of Moore (2010) can be applied on Hungarian banking sector. Positive sign of the coefficient signals that cyclical downturn should lower banks' expected transactions demand for money and therefore lead to decreased liquidity. Moreover, during expansionary phases, companies (which have higher profits) and households (which have higher income) might prefer to rely more on internal sources of finance and reduce the relative proportion of external financing and might reduce their debt levels. In recessions, households and corporations may increase their demand for bank credit in order to smooth out the impact of lower income and profits.

Determinants of liquidity measured by the ratio $L 2$ are presented in Table 4. Explanatory power of the model is substantially lower. This liquidity ratio is determined capital adequacy, interest margin and three different interest rates. The influence of capital adequacy on bank liquidity is the same as in case of previous ratio: bank which is solvent is liquid, too.

Results show also negative impact of interest margin which is logical: increase in interest margin stimulates bank to focus more on lending activity and as a result, the share of liquid assets is decreasing. Monetary policy interest rate can be considered as a measure of banks ability to provide loans to customers (Lucchetta, 2007). The link between liquid assets and monetary policy interest rate is therefore almost the same as in case of interest margin: the increase in monetary policy interest rates makes lending activity more attractive and thus leads to lower liquidity.

Table 4: Determinants of Liquidity Measured by L2

\begin{tabular}{|l|c|c|}
\hline Variable & Coefficient & Standard deviation \\
\hline Constant & -855527.1 & 558860.6 \\
\hline CAP & $67775.52^{*}$ & 8275.516 \\
\hline IRB & $-237152.3^{* *}$ & 125729.8 \\
\hline IRL & $419523.6^{* *}$ & 206619.8 \\
\hline IRM & $-246708.2^{* *}$ & 125712.0 \\
\hline MIR & $-190038.5^{* * *}$ & 120554.8 \\
\hline Adjusted $\mathrm{R}_{2}$ & 0.382408 \\
\hline Total observations & \multicolumn{2}{|c|}{245} \\
\hline
\end{tabular}

Source: author's estimation

Note: The starred coefficient estimates are significant at the $1 \%(*), 5 \%(* *)$ or $10 \%(* * *)$ level. 
Signs of two other coefficients correspond neither to our expectations nor to a standard economic theory. The results show the positive link between interest rate on loans and bank liquidity. Banks probably focus more on the interest margin or it can highlight the fact that higher lending rates do not encourage banks to lend more. This is consistent with the problem of credit crunch and credit rationing. The same can be true for the behavior of banks on the interbank market: the interest rate on interbank transactions is not the main factor which influences the incentives of banks to hold liquidity in the form of interbank deposits.

Table 5 shows determinants of liquidity measured by the last liquidity ratio L3. The explanatory power of this last model is slightly higher than the previous. The share of liquid assets on deposits and short term borrowing is determined only by two factors: by bank profitability and growth rate of GDP.

Table 5: Determinants of Liquidity Measured by L3

\begin{tabular}{|l|c|c|}
\hline Variable & Coefficient & Standard deviation \\
\hline Constant & $4523352 .^{*}$ & 1394440. \\
\hline ROE & $176061.1^{* *}$ & 84380.65 \\
\hline GDP & $-1090311 .^{*}$ & 327969.8 \\
\hline Adjusted ${ }^{2}$ & \multicolumn{2}{|c|}{0.463662} \\
\hline Total observation & \multicolumn{2}{|c|}{267} \\
\hline
\end{tabular}

Source: author's estimation

Note: The starred coefficient estimates are significant at the $1 \%(*), 5 \%(* *)$ or $10 \%(* * *)$ level.

The results show the positive link between profitability and liquidity, which is again inconsistent with standard economic theory. However, this can be explained by the impact of financial crisis: due to the crisis, profitability of many banks declined quite substantially (mainly due to the reduction of their lending activity), liquidity remains almost at the same level or slightly decreased.

The relation between growth rate of GDP and bank liquidity in this model completely differs from that described in Table 3. The results of this last model suggest that liquidity tends to be inversely related to the business cycle. Most borrowers want to take a loan during expansion when they have valuable investments projects. Banks which want to satisfy the growing demand for loans would face lower liquidity. During economic downturn, lending opportunities are not so good so banks hold higher share of liquid assets.

\section{Conclusion}

The aim of this paper was to identify determinants of liquidity of Hungarian commercial banks. We have used the panel data regression analysis for four liquidity ratios. We consider four bank specific factors and eight macroeconomic factors and nine of them were at least in some models statistically significant. The results of models enable us to make following conclusions.

Bank liquidity decreases with the size of the bank: big banks rely on the interbank market or on a liquidity assistance of the Lender of Last Resort, small and medium sized banks hold buffer of liquid assets which is fully in accordance with "too big to fail" hypothesis.

Liquidity is negatively influenced also by interest margin and monetary policy interest rate. Both factors lead to higher lending activity of banks and thus reduce bank liquidity. The interest rate on interbank transaction has negative impact on bank liquidity, too; however, we came to conclusion that the level of interest rate is not the main factor which influences the 
incentives of banks to hold liquidity in the form of interbank deposits.

On contrary, bank liquidity increases with higher capital adequacy of banks, higher interest rate on loans and higher bank profitability. As we have expected, solvent banks are liquid, too. However, the positive impact of interest rate on loans and bank profitability is very surprising and can be explained only by the fact that a simple increase in interest rate on loans may not have a direct impact on bank lending (and thus on bank liquidity) - interest margin is more important. We should not take into consideration the identified positive relationship between liquidity and profitability: as we have mentioned, during the financial crisis profitability of many banks declined quite substantially and liquidity remains almost at the same level or slightly decreased.

The relation between the growth rate of GDP and bank liquidity is ambiguous. We have also found that unemployment, share of nonperforming loans and financial crisis have no statistically significant effect on the liquidity of Hungarian commercial banks.

\section{Acknowledgement}

This paper was prepared with financial support of Czech Science Foundation - Project GAČR P403/11/P243 „Liquidity risk of commercial banks in the Visegrad countries“.

\section{References}

[1] ANDRIES, A. M. 2009. A comparative analysis of performance and soundness indicators of the main Romanian banks. Scientific Annals of the "Alexandru Ioan Cuza" University of Iasi: Economic Science Series, 56, 45-70. ISSN 0379-7864.

[2] ASPACHS, O., E. NIER and M. TIESSET, 2005. Liquidity, Banking Regulation and the Macroeconomy. Evidence on bank liquidity holdings from a panel of UK-resident banks. Bank of England Working Paper, 2005.

[3] BIS. 2008. Principles for Sound Liquidity Risk Management and Supervision. Basel: Bank for International Settlements. ISBN 92-9197-767-5.

[4] BIS. 2009. International framework for liquidity risk measurement, standards and monitoring. Basel: Bank for International Settlements. ISBN 92-9131-811-6.

[5] BUNDA, I. and J. B. DESQUILBET, 2008. The Bank Liquidity Smile Across Exchange Rate Regimes. International Economic Journal, 22(3), 361-386. ISSN 1743-517X.

[6] ČERNOHORSKÝ, J., P. TEPLÝ and M. VRÁBEL, 2010. Liquidity Market Support During the Global Crisis. Scientific Papers of the University Pardubice, 17(2), 39-49. ISSN 1211-555X.

[7] FIELDING, D. and A. SHORTLAND, 2005. Political Violence and Excess Liquidity in Egypt. Journal of Development Studies, 41(4), 542-557. ISSN 0225-5189.

[8] GHOSH, S. 2010. Credit Growth, Bank Soundness and Financial Fragility: Evidence from Indian Banking Sector. South Asia Economic Journal, 11(1), 69-98. ISSN 13915614.

[9] JIMÉNEZ, G., S. ONGENA, J. PEYDRÓ and J. SAURINA, 2010. Credit Supply: Identifying Balance-Sheet Channel with Loan Applications and Granted Loans. ECB Working Paper Series No. 1179/2010. 
[10]LUCCHETTA, M. 2007. What Do Data Say About Monetary Policy, Bank Liquidity and Bank Risk Taking? Economic Notes by Banca Monte dei Paschi di Siena SpA, 36(2), 189-203.

[11]MAECHLER, A.M., S. MITRA and D. WORRELL, 2007. Decomposing Financial Risks and Vulnerabilities in Eastern Europe. IMF Working Paper No. 248/2007.

[12]MOORE, W. 2010. How do financial crises affect commercial bank liquidity? Evidence from Latin America and the Caribbean. MPRA Paper No. 21473/2010.

[13]PRAET, P. and V. HERZBERG, 2008. Market liquidity and banking liquidity: linkages, vulnerabilities and the role of disclosure. In Banque de France Financial stability Review. Paris: Banque de France, pp. 95-109. ISSN 1637-4681.

[14]RAUCH, C., S. STEFFEN, A. HACKETHAL and M. TYRELL, 2010. Determinants of Bank Liquidity Creation. Available at: $<$ http://papers.ssrn.com/sol3/papers.cfm?abstract_id=1343595> [Accessed 20 June 2011].

[15]RYCHTÁRIK, Š. 2009. Liquidity Scenario Analysis in the Luxembourg Banking Sector. BCDL Working Paper No. 41/2009.

[16]TAMIRISA, N. T. and D. O. IGAN, 2008. Are Weak Banks Leading Credit Booms? Evidence from Emerging Europe. Comparative Economic Studies, 50(4), 599-619. ISSN 0888-7233.

[17]TEPLÝ, P. 2011. The Future Regulatory Challenges of Liquidity Risk Management. World Academy of Science, Engineering and Technology, 73, 945-949.

[18]VALLA, N., B. SAES-ESCORBIAC, and M. TIESSET, 2006. Bank liquidity and financial stability. In Banque de France Financial Stability Review, pp. 89-104. ISSN 1636-6964.

[19]VODOVÁ, P. 2011. Liquidity of Czech Commercial Banks and its Determinants, International Journal of Mathematical Models and Methods in Applied Sciences, 6, 10601067.

[20]VODOVÁ, P. 2012. Liquidity of Slovak Commercial Banks and its Determinants. In STAVÁREK, D., VODOVÁ, P. (ed.) Proceedings of the 13th International Conference on Finance and Banking. Karviná, Silesian University, pp. 487-494. 